\title{
PERBEDAAN KEMAMPUAN PENALARAN MATEMATIK SISWA YANG MEMPEROLEH PEMBELAJARAN KOOPERATIF TIPE STUDENTTEAM ACHIEVEMENT DIVISION DAN TEAMS GAMES TOURNAMENT BERBANTUAN GEOGEBRA DI KELAS VII SMP MUHAMMADIYAH 3 MEDAN
}

\author{
Nurhakiki $^{1}$, Katrina Samosir ${ }^{2}$ \\ ${ }^{1}$ Fakultas Matematika dan Ilmu Pengetahuan Alam, Universitas Negeri Medan \\ ${ }^{2}$ Dosen Fakultas Matematika dan Ilmu Pengetahuan Alam, Universitas Negeri Medan \\ Email: nurhakikialmalawy10@gmail.com
}

\begin{abstract}
ABSTRAK
Penelitian yang dilakukan di SMP Muhammadiyah 3 Medan ini bertujuan untuk mengetahui perbedaan kemampuan penalaran matematik siswa dengan menggunakan model pembelajaran kooperatif tipe Student Team Achievement Division berbantuan GeoGebra dan model pembelajaran kooperatif tipe Teams Games Tournament berbantuan GeoGebra di kelas. Populasi dalam penelitian ini adalah seluruh siswa kelas VII SMP Muhammadiyah 3 Medan yang terdiri dari 7 kelas. Sedangkan yang menjadi sampel dalam penelitian ini ada dua kelas, yaitu kelas VII-B yang berjumlah 27 orang yang memperoleh pembelajaran koooperatif tipe STAD sebagai kelas eksperimen I dan kelas VII-A yang berjumlah 24 orang yang memperoleh pembelajaran koooperatif tipe TGT sebagai kelas eksperimen II. Penentuan sampel dilakukan secara acak. Instrumen yang digunakan dalam penelitian ini adalah tes berbentuk uraian sebanyak 5 soal yang telah dinyatakan valid. Berdasarkan hasil penelitian dan pengujian hipotesis dapat disimpulkan bahwa kemampuan penalaran matematik siswa yang memperoleh pembelajaran koooperatif tipe STAD berbantuan GeoGebra lebih tinggi daripada siswa yang memperoleh pembelajaran koooperatif tipe TGT berbantuan GeoGebra pada materi jajargenjang dan belah ketupat, dengan $t_{\text {hitung }}=$ 3,15 dan $t_{\text {tabel }}=1,68$ pada taraf nyata $\alpha=0,05$ dan $d k=49$. Karena $t_{\text {hitung }}>t_{\text {tabel }}$ yaitu 3,15 > 1,68 maka dapat disimpulkan bahwa $H_{a}$ diterima yang berarti kemampuan penalaran matematik siswa yang memperoleh pembelajaran kooperatif tipe STAD berbantuan GeoGebra lebih tinggi daripada siswa yang memperoleh pembelajaran kooperatif tipe TGT berbantuan GeoGebra pada materi jajargenjang dan belah ketupat. Rata-rata nilai postes kelas eksperimen I lebih tinggi daripada rata-rata nilai postes kelas eksperimen II yaitu 75,67 dengan standar deviasi 23,12 dan 70,96 dengan standar deviasi 34,25 .
\end{abstract}

Kata Kunci : Kemampuan Penalaran Matematik, Student Team Achievement Division, Teams Games Tournament, GeoGebra

\section{ABSRACT}

This study is conducted in SMP Muhammadiyah 3 Medan aims to know the difference of a mathematic reasoning ability by using cooperative learning model types Student Team Achievement Division and GeoGebra and cooperative learning model types Teams Games Tournament and GeoGebra in grade VII. The population of this study is all students grade VII SMP Muhammadiyah 3 Medan consistings of 7 classes. While the sample of this study is

Nurhakiki, Katrina Samosir. Perbedaan Kemampuan Penalaran Matematik Siswa yang Memperoleh Pembelajaran Kooperatif Tipe Student Team Achievement Division dan Teams Games Toumament Berbantuan Geogebra di Kelas VII SMP Muhammadiyah 3 Medan. Jurnal Inspiratif, Vol. 3 No. 1 April 2017. 
two classes namely grade VII-B consistings of 27 students whom got cooperative learning typed STAD as an experimental class I and grade VII-A consistings of 24 students whom got cooperative learning typed TGT as an experimental class II. The determination of the sample is randomly conducted. The instrument used in this study is essay test as many as 5 tests which are claimed valid. Based on the result of the study and testing the hypothesis can be concluded that students' mathematic reasoning ability which get cooperative learning typed STAD and GeoGebra are higher than students who get cooperative learning typed TGT and GeoGebra at array and belah ketupat, tcount $=3,15$ and ttable $=1,68$ taraf nyata $\alpha=0,05$ dan $d k=49$. Because $t_{\text {count }}>t_{\text {table }}$ yaitu $3,15>1,68$, thus can be concluded that $H_{a}$ is accepted, means students' mathematic reasoning ability who get cooperative learning model typed STAD and GeoGebra are higher than the students who get cooperative learning typed TGT and GeoGebra at array and belah ketupat array. The average of experimental class I post-test is higher than the average of experimental class II namely 75,67 and its deviation standard is 23,12 while 70,96 and its deviation standard is 34,25.

Keywords : mathematic reasoning ability, Student Team Achievement Division, Teams Games Tournament, GeoGebra

\section{Pendahuluan}

Pendidikan merupakan salah satu faktor yang menentukan kemajuan bangsa. Pendidikan membantu manusia dalam mengembangkan potensi dirinya sehingga mampu menghadapi segala perubahan yang terjadi, sebagaimana tercantum dalam UU No. 20 Tahun 2003 tentang Sistem Pendidikan Nasional. Sesuai dengan sistem pendidikan nasional yang tertuang dalam UU No. 20 Tahun 2003 tersebut, pelaksanaan pendidikan tentunya perlu mendapat proporsi yang cukup untuk menghasilkan output yang unggul. Oleh karena itu mutu pendidikan sangat diperlukan untuk mendukung terciptanya manusia cerdas, terbuka, dan demokratis serta mampu untuk bersaing secara terbuka di era globalisasi.

Dari berbagai bidang studi yang diajarkan di sekolah, matematika merupakan salah satu bidang yang menduduki peranan penting dalam pendidikan, hal ini dapat dilihat dari jam pelajaran matematika di sekolah yang lebih banyak jika dibandingkan dengan pelajaran yang lain. Hal ini disebabkan matematika merupakan suatu sarana berpikir untuk mengkaji sesuatu secara logis dan sistematis. Matematika sangat diperlukan untuk kehidupan sehari-hari dalam menghadapi kemajuan IPTEK.

Penalaran dalam matematika memiliki peran yang sangat penting dalam proses berpikir seseorang. Penalaran juga merupakan pondasi dalam pembelajaran matematika. Bila kemampuan bernalar siswa tidak dikembangkan, maka bagi siswa, matematika hanya akan menjadi materi yang mengikuti serangkaian prosedur dan meniru contoh-contoh tanpa mengetahui maknanya.

Cara pandang siswa tentang persoalan matematika akan mempengaruhi pola pikir tentang penyelesaian yang akan dilakukan. Salah satu tujuan dari pembelajaran matematika adalah agar siswa mampu menggunakan penalaran pada pola dan sifat, melakukan manipulasi matematika dalam membuat generalisasi, menyusun bukti, atau menjelaskan gagasan dan pernyataan matematika.

Hal tersebut senada dengan penjelasan Peraturan Dirjen Dikdasmen Depdiknas No. 506/C/PP/2004 (dalam Shadiq, 2009: 14) menyatakan tentang indikator dari penalaran dan komunikasi. Dalam hal ini peneliti memilih beberapa indikator yang sesuai terhadap

Nurhakiki, Katrina Samosir. Perbedaan Kemampuan Penalaran Matematik Siswa yang Memperoleh Pembelajaran Kooperatif Tipe Student Team Achievement Division dan Teams Games Toumament Berbantuan Geogebra di Kelas VII SMP Muhammadiyah 3 Medan. Jurnal Inspiratif, Vol. 3 No. 1 April 2017. 
peningkatan kemampuan penalaran matematik siswa antara lain sebagai berikut: (1) menyajikan pernyataan matematika secara lisan, tertulis, gambar, dan diagram; (2) mengajukan dugaan; (3) melakukan manipulasi matematika; dan (4) menarik kesimpulan, menyusun bukti, memberikan alasan; (5) menarik kesimpulan dari pernyataan; (6) memeriksa kesimpulan dari pernyataan; (7) menemukan pola atau sifat dari gejala matematis untuk membuat generalisasi.

Berdasarkan informasi yang diperoleh dari guru bidang studi matematika di SMP Muhammadiyah 3 Medan (4 Februari 2017) yang mengatakan bahwa pada umumnya siswa akan kebingungan mengerjakan soal apabila dalam pembelajaran diberikan contoh yang berbeda dari soal yang harus dikerjakan. Hal ini mengindikasikan bahwa siswa tidak mampu menguasai materi dengan baik karena biasanya siswa hanya menghapal rumus atau cara pengerjaan contoh soal tanpa menggunakan kemampuan penalarannya. Kemudian pelaksanaan pembelajaran matematika saat ini yang masih didominasi oleh guru membuat keterlibatan siswa belum optimal.

Dalam upaya meningkatkan kemampuan penalaran matematik siswa diperlukan suatu model pembelajaran yang tepat. Salah satunya adalah model pembelajaran kooperatif. Dalam proses belajar yang menggunakan model pembelajaran kooperatif, siswa belajar bersama sebagai suatu tim dalam menyelesaikan tugas-tugas kelompok untuk mencapai tujuan bersama. Jadi, setiap anggota kelompok memiliki tanggung jawab yang sama untuk keberhasilan kelompoknya. Beberapa ahli menyatakan bahwa model ini tidak hanya unggul dalam membantu siswa memahami konsep yang sulit, tetapi juga sangat berguna untuk menumbuhkan kemampuan berpikir kritis,bekerjasama, dan membantu teman. Hal ini didukung oleh hasil penelitian yang dilakukan oleh Slavin (dalam Rusman, 2012: 205) menyatakan bahwa:

(1) Penggunaan pembelajaran kooperatif dapat meningkatkan prestasi belajar siswa dan sekaligus dapat meningkatkan hubungan sosial, menumbuhkan sikap toleransi, dan menghargai pendapat orang lain, (2) pembelajaran kooperatif dapat memenuhi kebutuhan siswa dalam berpikir kritis, memecahkan masalah, dan mengintegrasikan pengetahuan dengan pengalaman.

Dalam model pembelajarn kooperatif, guru tidak hanya memberikan pengetahuan pada siswa, tetapi juga harus membangun pengetahuan dalam pikirannya. Siswa memiliki kesempatan untuk mendapatkan pengalaman langsung dalam menerapkan ide-ide mereka, ini merupakan kesempatan bagi siswa untuk menemukan dan menerapkan ide-ide mereka sendiri (Rusman, 2012: 201).

Dengan menggunakan model pembelajaran kooperatif dengan sistem berdiskusi maka siswa diharapkan dapat meningkatkan daya nalar, keterlibatan siswa dalam pembelajaran akan memberikan kesempatan kepada siswa untuk mengungkapkan pendapatnya. Untuk meningkatkan daya penalaran siswa, maka siswa dituntut untuk mampu mengajukan dugaan, menyusun bukti baru, serta menarik kesimpulan yang logis dari pernyataan yang ada melalui diskusi antar anggota kelompok.

Kemudian tuntutan yang diberikan pada siswa untuk saling belajar mengajar sesama mereka membentuk setiap siswa untuk bertanggung jawab memahami materi pelajaran terlebih dahulu. Slavin (dalam Sanjaya, 2006: 242) juga mengatakan bahwa :

(1) Beberapa hasil penelitian membuktikan bahwa penggunaan pembelajaran kooperatif dapat

Nurhakiki, Katrina Samosir. Perbedaan Kemampuan Penalaran Matematik Siswa yang Memperoleh Pembelajaran Kooperatif Tipe Student Team Achievement Division dan Teams Games Toumament Berbantuan Geogebra di Kelas VII SMP Muhammadiyah 3 Medan. Jurnal Inspiratif, Vol. 3 No. 1 April 2017. 
meningkatkan prestasi belajar siswa sekaligus dapat meningkatkan kemampuan hubungan sosial, menumbuhkan sikap menerima kekurangan diri dan orang lain, serta dapat meningkatkan harga diri, dan (2) pembelajaran kooperatif dapat merealisasikan kebutuhan siswa dalam belajar berpikir, memecahkan masalah, dan mengintegrasikan pengetahuan dengan keterampilan.

Berdasarkan dua alasan tersebut, maka pembelajaran kooperatif merupakan bentuk pembelajaran yang dapat memperbaiki sistem pembelajaran yang selama ini memiliki kelemahan. Melalui diskusi akan terjadi elaborasi kognitif yang baik, sehingga dapat meningkatkan daya nalar, keterlibatan siswa dalam pembelajaran akan memberi kesempatan pada siswa untuk mengungkapkan pendapatnya. Model pembelajaran kooperatif diharapkan dapat membantu meningkatkan kemampuan bernalar, yaitu dengan adanya pembelajaran kooperatif siswa dituntut untuk mampu mengajukan dugaan, menyusun bukti baru, serta menarik kesimpulan yang logis dari pernyataan yang ada melalui diskusi antar anggota kelompok.

Pembelajaran Think Talk Write diperkenalkan oleh Huinker dan Laughlin pada tahun 1996. Pada dasarnya pembelajaran tersebut dibangun melalui tiga aktivitas utama yaitu berpikir (Think), berbicara (Talk), dan menulis (Write). Tahap think diawali dengan kegiatan siswa memikirkan permasalahan yang diberikan. Hal tersebut membuat siswa harus aktif mengeksplorasi kemampuannya untuk memahami masalah, mengidentifikasi data yang diperlukan untuk memecahkan masalah, memunculkan beragam ide matematika, dan menyatakannya dalam bentuk tulisan untuk didiskusikan dengan teman sekelompoknya.
Diantara berbagai tipe pembelajaran kooperatif, sesuai dengan karakteristik maka pembelajaran kooperatif tipe Student Team Achievement Division (STAD) dan Teams Games Tournament (TGT) diperkirakan akan dapat diterapkan dikelas.

Model pembelajaran kooperatif tipe Student Team Achievement Division (STAD) dikembangkan oleh Robert Slavin di John Hopkins. Pembelajaran kooperatif tip STAD merupakan salah satu tipe dari model pembelajaran kooperatif dengan menggunakan kelompok-kelompok kecil dengan jumlah anggota tiap kelompok 4-5 orang siswa secara heterogen (Trianto, 2009: 68). Teknik belajar mengajar tipe STAD ini adalah siswa yang memiliki kemampuan diatas rata-rata akan menularkan kemampuan matematikanya kepada temannya yang berkemampuan matematika rendah, sehingga kemampuan penalaran siswa dapat berkembang karena saling berbagi informasi dan pengetahuan.

Pelaksanaan

pembelajaran matematika dengan menggunakan model pembelajaran kooperatif tipe STAD turut melibatkan aktivitas bernalar. Di dalam pembelajaran kooperatif tipe STAD, semua siswa dituntut untuk dapat mengerti semua materi yang dipelajari. Hal ini berarti bahwa siswa saling memberikan pengetahuan yang dimiliki untuk menumbuhkembangkan kemampuan penalarannya sehingga siswa terlatih untuk bernalar. Senada dengan hasil penelitian Tri Muhti Haryani dan Ety Septiati (2011) menyimpulkan bahwa kemampuan penalaran matematik siswa melalui model pembelajaran kooperatif tipe STAD adalah baik. Kemudian dalam penelitian Nur Nikmah (2014) menyimpulkan bahwa kemampuan penalaran matematika siswa meningkat melalui model pembelajaran kooperatif

Nurhakiki, Katrina Samosir. Perbedaan Kemampuan Penalaran Matematik Siswa yang Memperoleh Pembelajaran Kooperatif Tipe Student Team Achievement Division dan Teams Games Toumament Berbantuan Geogebra di Kelas VII SMP Muhammadiyah 3 Medan. Jurnal Inspiratif, Vol. 3 No. 1 April 2017. 
tipe STAD dengan pendekatan investigasi.

Sedangkan model pembelajaran kooperatif tipe Teams Games Tournament (TGT) atau Pertandingan Permainan Tim yang dikembangkan oleh David De Vries dan Keath Edward (1995). Pada model ini siswa memainkan permaian dengan anggotaanggota tim lain untuk memperoleh tambahan poin untuk skor tim mereka (Trianto, 2009: 83). Model pembelajaran kooperatif tipe Teams Games Tournament (TGT) merupakan model pembelajaran kooperatif yang didalamnya terdapat unsur permainan akademik atau turnamen untuk mengganti tugas individu. Sehingga siswa tidak merasakan bosan karena ada unsur turnamen.

Sebelum memulai game dan turnamen akademik, perlu terlebih dahulu menempatkan siswa dalam sebuah tim yang mewakili heterogenitas kelas ditinjau dari segi akademik, jenis kelamin, ras, maupun etnis. Masingmasing siswa nantinya akan mewakili kelompoknya untuk bersaing dalam meja turnamen. Setelah kelas dibagi menjadi beberapa kelompok kecil, guru kemudian menyajikan materi dan selanjutnya siswa bekerja mengerjakan LAS dalam kelompoknya masingmasing. Apabila ada anggota kelompok yang kurang mengerti dengan materi dan tugas yang diberikan, maka anggota kelompok yang lain bertugas memberikan jawaban serta menjelaskannya sebelum pertanyaan tersebut diajukan kepada guru.

Ketika turnamen akademik, siswa akan dipisahkan dengan kelompok asalnya untuk ditempatkan dalam mejameja turnamen. Setiap meja turnamen terdiri dari beberapa sisiwa yang mewakili kelompoknya masing-masing. Penentuan dimana meja turnamen yang akan ditempati oleh siswa dilakukan oleh guru, yaitu dengan melihat homogenitas akademik. Maksudnya, siswa yang berada dalam satu meja turnamen adalah siswa dengan kemampuan akademiknya setara. Sehingga terdapat kompetisi antar kelompok yang dikemas dalam suatu permainan yang siswa aktif dalam pembelajaran dan keterlibatan siswa dalam memecahkan persoalan memberi peluang untuk menambah pemahaman siswa, sehingga memungkinkan penalaran matematik siswa menjadi lebih baik. Hal tersebut didukung oleh Nur Ainun, dkk (dalam Jurnal Didaktit Matematika Universitas Syiah Kuala Vol. 2 Nomor 1 Tahun 2015) yang menyatakan bahwa "Peningkatan kemampuan penalaran matematik sisiwa yang memperoleh pembelajaran dengan model pembelajaran kooperatif tipe Teams Games Tournament lebih baik dari siswa yang memperoleh pendekatan konvensional ditinjau dari keseluruhan dan subkelompok siswa (tinggi, sedang, rendah)".

Kemudian, faktor lain yang dapat mempengaruhi proses belajar mengajar adalah penggunaan media dalam proses pembelajaran itu sendiri. Maka dari itu, perlu digunakan media pembelajaran yang mampu memfasilitasi siswa untuk melakukan ekplorasi yang berkaitan dengan materi jajargenjang dan belah ketupat.

Untuk itu diperlukan suatu media pembelajaran yang diharapkan dapat membantu siswa dapat memahami materi dan meningkatkan penalaran matematik siswa. Salah satu media inovatif yang dapat menyajikan objek abstrak menjadi dapat dipahami dan diamati adalah software komputer. Penggunan software komputer dalam pembelajaran sangat bermanfaat, misalnnya dapat memperjelas penyampaian materi, membantu proses perhitungan yang sulit, serta menjadikan pembelajaran lebih menyenangkan dan dapat menciptakan iklim belajar yang efektif untuk mengoptimalkan kemampuan penalaran matematik siswa.

Nurhakiki, Katrina Samosir. Perbedaan Kemampuan Penalaran Matematik Siswa yang Memperoleh Pembelajaran Kooperatif Tipe Student Team Achievement Division dan Teams Games Toumament Berbantuan Geogebra di Kelas VII SMP Muhammadiyah 3 Medan. Jurnal Inspiratif, Vol. 3 No. 1 April 2017. 
Salah satunya adalah media pembelajaran berbantuan komputer yang mampu memfasilitasi siswa untuk melakukan eksplorasi yang berkaitan dengan materi jajargenjang dan belah ketupat adalah GeoGebra. GeoGebra adalah program komputer (software) untuk membelajarkan matematika. GeoGebra dapat membantu siswa mengamati objek-objek abstrak dalam jajargenjang dan belah ketupat dan menjadikannya terlihat lebih nyata.

\section{Metode Penelitian}

Penelitian ini dilaksanakan di SMP Muhammadiyah 3 Medan yang berlokasi di Jalan Abdul Hakim No. 2 Tanjung Sari pada semester genap. Variabel bebas dalam penelitian ini adalah pembelajaran kooperatif tipe STAD dan TGT. Sedangkan variabel terikatnya adalah kemampuan penalaran matematik siswa.

Jenis penelitian yang digunakan dalam penelitian ini adalah eksperimen semu yang bertujuan untuk mengetahui perbedaan kemampuan penalaran matematik siswa yang diajar menggunakan model pembelajaran kooperatif tipe STAD dan TGT di Kelas VII SMP Muhammadiyah 3 Medan. Populasi dalam penelitian ini adalah seluruh siswa kelas VIII yang terdiri dari 7 kelas dengan jumlah 237 siswa. Sedangkan sampelnya yaitu kelas VII-B yang berjumlah 27 orang dan VII-A yang berjumlah 24. Desain penelitian yang digunakan dalam penelitian ini adalah Post-Test Only Control Group Design. Instrumen yang digunakan dalam penelitian ini adalah tes kemampuan penalaran matematik siswa (post-test). Analisis data dalam penelitian ini terdiri dari pengujian normalitas, pengujian homogenitas, dan pengujian hipotesis.

\section{Hasil Penelitian dan Pembahasan}

Sebelum penelitian ini dilaksanakan, peneliti terlebih dahulu mengujicobakan instrumen-instrumen penelitian diluar sampel penelitian. Untuk menafsirkan keberartian harga validitas setiap item soal, maka harga $\mathrm{r}_{\text {hitung }}$ tersebut dibandingkan dengan nilai $r_{\text {tabel }}(0,361)$, dengan kriteria jika $r_{\text {hitung }}>$

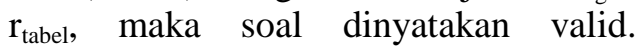
Perhitungan reliabilitas soal post-test, diperoleh $r_{\text {hitung }}(0,361)$ sehingga $r_{\text {hitung }}>$ $\mathrm{r}_{\text {tabel }}$ dikatakan reliabel. Dari perhitungan uji validitas dan reliabilitas tes yang dinyatakan valid dan reliabel, maka seluruh soal post-test kemampuan penalaran matematik siswa dapat dipakai untuk penelitian ini.

Setelah kedua kelas diberi perlakuan yang berbeda yaitu dengan model pembelajaran kooperatif tipe STAD untuk kelas Eksperimen I dan model pembelajaran kooperatif tipe TGT untuk kelas Eksperimen II, kemudian siswa diberikan post-test untuk mengetahui kemampuan komunikasi matematis. Dari hasil penelitian diperoleh nilai rata-rata posttest pada kelas Eksperimen I adalah 75,67dan nilai rata-rata post-test pada kelas Eksperimen II adalah 70,96. Berdasarkan hasil analisis data post-test diperoleh kedua kelas memiliki nilai $L_{0}<L_{\text {tabel }}$ yaitu $0,1535<0,1682$ (kelas Eksperimen I) dan 0,1516 < 0,1764 (kelas Eksperimen II) sehingga dapat disimpulkan kelas Eksperimen I dan kelas Eksperimen II berdistribusi normal. Pada pengujian homogenitas diperoleh $\quad F_{\text {hitung }}<F_{\text {tabel }} \quad$ yaitu $1,4811<1,976$ sehingga dapat disimpulkan bahwa kedua sampel homogen.

Selanjutnya dilakukan pengujian hipotesis dengan menggunakan uji t. Setelah dilakukan pengujian data ternyata diperoleh $t_{\text {hitung }}>t_{\text {tabel }}$ yaitu $3,15231>1,6755$ maka dapat disimpulkan bahwa $H_{0}$ ditolak dan $H_{a}$ diterima yaitu bahwa Kemampuan penalaran matematik siswa yang

Nurhakiki, Katrina Samosir. Perbedaan Kemampuan Penalaran Matematik Siswa yang Memperoleh Pembelajaran Kooperatif Tipe Student Team Achievement Division dan Teams Games Toumament Berbantuan Geogebra di Kelas VII SMP Muhammadiyah 3 Medan. Jurnal Inspiratif, Vol. 3 No. 1 April 2017. 
memperoleh pembelajaran kooperatif tipe STAD berbantuan GeoGebra lebih tinggi daripada siswa yang memperoleh pembelajaran kooperatif tipe TGT berbantuan GeoGebra di kelas VII SMP Muhammadiyah 3 Medan.

Perbedaan yang paling mendasar antara model pembelajaran kooperatif tipe STAD dan model pembelajaran kooperatif tipe TGT yang paling mendasar adalah model pembelajaran kooperatif tipe STAD yang digunanakan di kelas eksperimen I ini, konsep dasar materi diterangkan langsung oleh guru lalu siswa mengerjakan LAS secara berkelompok.Teknik belajar mengajar tipe STAD ini adalah siswa yang memiliki kemampuan diatas rata-rata akan menularkan kemampuan matematikanya kepada temannya yang berkemampuan matematika rendah, sehingga kemampuan penalaran siswa dapat berkembang karena saling berbagi informasi dan pengetahuan.

Pelaksanaan

pembelajaran matematika dengan menggunakan model pembelajaran kooperatif tipe STAD turut melibatkan aktivitas bernalar. Di dalam pembelajaran kooperatif tipe STAD, semua siswa dituntut untuk dapat mengerti semua materi yang dipelajari. Hal ini berarti bahwa siswa saling memberikan pengetahuan yang dimiliki untuk menumbuhkembangkan kemampuan penalarannya sehingga siswa terlatih untuk bernalar. Setelah siswa mengerjakan LAS, kemudian akan diadakan kuis yang yaitu berupa pemberan latihan yang dikerjakan secara individu untuk kemudian nilai kuis setiap individu akan diakumulasikan ke dalam nilai kelompok.

Sedangkan model pembelajaran kooperatif tipe TGT yang digunakan di kelas eksperimen II ini setelah siswa mengerjakan LAS, kemudian siswa memainkan permaian dengan anggotaanggota tim lain untuk memperoleh tambahan poin untuk skor tim mereka Model pembelajaran kooperatif tipe
TGT merupakan model pembelajaran kooperatif yang didalamnya terdapat unsur permainan akademik atau turnamen untuk mengganti tugas individu.

Ketika turnamen akademik, siswa akan dipisahkan dengan kelompok asalnya untuk ditempatkan dalam mejameja turnamen. Setiap meja turnamen terdiri dari beberapa sisiwa yang mewakili kelompoknya masing-masing. Penentuan dimana meja turnamen yang akan ditempati oleh siswa dilakukan oleh guru, yaitu dengan melihat homogenitas akademik.

Hasil penelitian ini sejalan dengan penelitian yang dilakukan oleh penelitian yang dilakukan oleh Tri Muhti dan Ety Septiati (2011) menyimpulkan bahwa kemampuan penalaran matematik siswa melalui model pembelajaran koopertaif tipe STAD dikategorikan baik.

Dari pembahasan di atas, adanya teori belajar yang mendukung dan penelitian yang relevan yang peneliti jelaskan di atas, maka dapat disimpulkan bahwa model pembelajaran kooperatif tipe Student Team Achievement Division (STAD) lebih tinggi daripada model pembelajaran kooperatif tipe Team Games Tournament (TGT).

\section{Kesimpulan}

Berdasarkan hasil penelitian maka dapat disimpulkan bahwa kemampuan penalaran matematik siswa yang memperoleh pembelajaran kooperatif tipe STAD berbantuan GeoGebra lebih tinggi daripada kemampuan penalaran matematik siswa yang memperoleh pembelajaran kooperatif tipe TGT berbantuan GeoGebra pada materi jajargenjang dan belah ketupat di kelas VII SMP Muhammadiyah 3 Medan.

Saran

Nurhakiki, Katrina Samosir. Perbedaan Kemampuan Penalaran Matematik Siswa yang Memperoleh Pembelajaran Kooperatif Tipe Student Team Achievement Division dan Teams Games Toumament Berbantuan Geogebra di Kelas VII SMP Muhammadiyah 3 Medan. Jurnal Inspiratif, Vol. 3 No. 1 April 2017. 
Berdasarkan hasil penelitian ini maka saran yang dapat peneliti berikan adalah :

1. Kepada tenaga pengajar matematika agar dapat menjadikan model pembelajaran kooperatif tipe STAD ataupun TGT sebagai salah satu alternatif dalam memilih model pembelajaran yang diharapkan dapat meningkatkan kemampuan penalaran matematika siswa.

2. Bagi guru atau calon guru yang akan menggunakan model pembelajaran kooperatif tipe STAD ataupun TGT agar memperhatikan alokasi waktu yang tersedia agar seluruh tahapan-tahapan pembelajaran kooperatif tersebut dapat dilaksanakan dengan baik sehingga diperoleh hasil yang memuaskan.

3. Bagi peneliti selanjutnya dapat melanjutkan penelitian tentang model pembelajaran kooperatif tipe STAD dan TGT dengan pokok bahasan dan sekolah yang berbeda, juga menyertakan variabel yang lebih kompleks.

\section{DAFTAR PUSTAKA}

Abdurrahman, M., (2003), Pendidikan Bagi Anak Berkesulitan Belajar, Rineka Cipta, Jakarta.

Arikunto, S., (2009), Manajemen Penelitian, PT Rineka Cipta, Jakarta.

Ainun, N., dkk., (2015), Peningkatan Kemampuan Komunikasi dan Penalaran Matematika Siswa Madrasah Aliyah melalui Model Pembelajaran Kooperatif Tipe Teams Games Tournament, Jurnal Didaktik Matematika 2 : 71-83

Aryani, T., dan Septiati, E., (2011), Kemampuan Penalaran Matematis Siswa Melalui Model Pembelajaran Kooperatif Tipe
STAD di SMPN 7 Palembang, Prosiding Juni 2011.

Depdiknas., 2006, Permendiknas Nomor 22 Thun 2006 Tentang Standar Isi Mata Pelajaran Matematika. Depdiknaas, Jakarta.

Dewi, N., dkk., (2008), Matematika Konsep dan Aplikasi Untuk SMP \& MTs Kelas VII, Pustaka Perbukuan, Dapartemen Pendidikan Nasional.

Djumanta, W., (2008), Mari Memahami Konsep Matematika Untuk Kelas VII, Pustaka Perbukuan, Dapartemen Pendidikan Nasional.

Hendriana, H. Dan Soemarmo, U., (2014), Penilaian Pembelajaran Matematika, PT Refika Aditama, Bandung.

Isjoni., (2009), Cooperative Learning, Penerbit Alfabeta, Bandung.

Istarani., (2012), $58 \quad$ Model Pembelajaran Inovatif, Media Persada, Medan.

Lestari, K.E., dan Yudhanegara, M.R., (2015), Penelitian Pendidikan Matematika, PT Refika Aditama, Bandung.

Lie, A., (2002), Cooperative Learning: Mempraktikkan Cooperative Learning di Ruang-Ruang Kelas, PT Grasindo, Jakarta.

Muharom, T., (2014), Pengaruh Pembelajaran dengan Model Kooperatif Tipe Student Teams Achievement Division (STAD) terhadap Kemampuan Penalaran dan Komunikasi Matematik Peserta Didik Di SMK Negeri Manonjaya Kabupaten Tasikmalaya, Jurnal Pendidikan 1: 1-11.

Nikmah, N., (2014), Upaya Meningkatkan Kemampuan Penalaran Matematika Siswa Kelas IX SMP Negeri 12 Medan pada Materi Bangun Ruang Sisi Lengkung dalam Pembelajaran Matematika Melalui Model

Nurhakiki, Katrina Samosir. Perbedaan Kemampuan Penalaran Matematik Siswa yang Memperoleh Pembelajaran Kooperatif Tipe Student Team Achievement Division dan Teams Games Toumament Berbantuan Geogebra di Kelas VII SMP Muhammadiyah 3 Medan. Jurnal Inspiratif, Vol. 3 No. 1 April 2017. 
Pembelajaran Kooperatif Tipe STAD dengan Pendekatan Investigasi, Skripsi, FMIPA, UNIMED.

Rosita, C.D., (2009), Kemampuan Penalaran dan Komunikasi Matematis : Apa, Mengapa, dan Bagaimana Ditingkatkan pada Mahasiswa, Jurnal Euclid 1 : 33-46.

Rusman., (2012), Model-Model Pembelajaran (Mengembangkan Profesionalisme Guru), Raja Grafindo Persada, Jakarta.

Sanjaya, W., (2006), Strategi Pembelajaran Berorientasi Ssatndart Proses Pendidikan, Kencana Prenandamedia Group, Jakarta.

Shadiq, F., (2009), Kemahiran Matematika, Pusat Perkembangan dan Pemberdayaan Pendidikan dan Tenaga Kependidikan Matematika, Yogyakarta.

Slavin, R. E., (2005), Cooperative Learning: Teori, Riset, Praktik, Penerbit Nusa Media, Bandung.

Sudjana., (2005), Metode Statistika, Tarsito, Bandung.

Sudjana., (2016), Metoda Statistika, Tarsito, Bandung. 